\title{
The Influences of Heat Treatment on the Microstructure and Mechanical Properties of 3.5Ni Steel
}

\author{
Liu Wenbin \\ Research and Development Center \\ Wuhan Iron and Steel (Group) Corp \\ Wuhan, China, 86-027-86487657 \\ liuwenbin2004@163.com
}

\author{
Luo Yi \\ Research and Development Center \\ Wuhan Iron and Steel (Group) Corp \\ Wuhan, China, 86-027-86487657 \\ luoyileyi@163.com
}

\begin{abstract}
The influence of heat treatment on microstructure and mechanical properties of $3.5 \mathrm{Ni}$ steel has been studied in this paper. The experiment results showed that the microstructure and grain of the normalized and tempered steel exhibited a low uniformity, which deteriorated toughness. The grain could be refined after quenching and tempering, and the carbides were recognized dispersing at grain boundaries, the low temperature toughness was improved. After secondary quenched and tempered, the size of grains became smaller, and the low temperature toughness was better.
\end{abstract}

Keywords-component; low temperature pressure vessel; microstructure; low temperature toughness; 3.5Ni; quenching; tempering.

\section{FOREWORD}

The pressure vessels designed temperature below $-20^{\circ} \mathrm{C}$ (such as liquefied ethylene, liquefied natural gas, liquid nitrogen, liquid hydrogen and other containers for producing and storing) were called the low temperature pressure vessels, steels for manufacturing these containers were called low temperature pressure vessel steel. The $\mathrm{Ni}$ series low temperature vessel steel was an very important one, its temperature range was $-40^{\circ} \mathrm{C} \sim-196^{\circ} \mathrm{C}$, and it can satisfy the most manufacturing requirements of the low temperature pressure vessels. Its low temperature toughness was outstanding, and its cost was lower than that of the $\mathrm{Cr}-\mathrm{Ni}$ stainless steel, so it had been widely used in the United States, Japan and other developed countries. 3.5Ni steel was typical one, and it was mainly used for manufacturing equipment of oil and air separation, and methanol washing tower, $\mathrm{H}_{2} \mathrm{~S}$ concentration tower, $\mathrm{CO}_{2}$ tower and other equipment for synthetic ammonia. It was generally used at $-101^{\circ} \mathrm{C}$, but it can also work between $-110{ }^{\circ} \mathrm{C}$ and $120{ }^{\circ} \mathrm{C}$. There were some standards for the Ni series low temperature steels in china, and had manufactured related products, but the industrial production scale were small, and most of them depend on importing. At present, domestic steel enterprises have conditions to produce $3.5 \mathrm{Ni}$ low temperature steels. But their performance was not always excellent, for example, bad low cryogenic toughness. Though there were some research work on low temperature toughness of the $3.5 \mathrm{Ni}$ steel, its related heat treatment process was not comprehensive ${ }^{[1 \sim 3]}$.So, this paper introduced the effect of different heat treatment process on the mechanical property of $3.5 \mathrm{Ni}$ steel.

\section{EXPERIMENTAL PROCEDURES}

\section{A. Chemical composition}

$3.5 \mathrm{Ni}$ steel was smelt by converter and secondary refining, and section size of its casting billet is $250 \mathrm{~mm} \times 1550 \mathrm{~mm}$, then it was rolled into the steel plates with $36 \mathrm{~mm}, 60 \mathrm{~mm}$ thickness in $2800 \mathrm{~mm}$ rolling mill. Its chemical composition is given in Table 1 .

TABLE 1 ChemicAl COMPOSITION OF 3.5Ni（WT\% )

\begin{tabular}{cccccc}
\hline $\mathrm{C}$ & $\mathrm{Si}$ & $\mathrm{Mn}$ & $\mathrm{P}$ & $\mathrm{S}$ & $\mathrm{Ni}$ \\
\hline$\leq 0.08$ & $\leq 0.30$ & $\leq 0.80$ & 0.008 & 0.005 & 3.55 \\
\hline
\end{tabular}

\section{B. Heat treatment}

The temperature of $\mathrm{A}_{\mathrm{c} 3}$ is $797{ }^{\circ} \mathrm{C}$, according to experience formula $\left(\mathrm{A}_{\mathrm{c} 3}=910-203 \mathrm{C}^{1 / 2}+44.7 \mathrm{Si}-15.2 \mathrm{Ni}+31.5 \mathrm{Mo}+104\right.$ $\mathrm{V}-30 \mathrm{Mn}+11 \mathrm{Cr}+20 \mathrm{Cu}-700 \mathrm{P}-400 \mathrm{Al}-120 \mathrm{As}-400 \mathrm{Ti}^{[6]}$ ). The phase transformation temperature was measured at heating and cooling rate of $0.05^{\circ} \mathrm{C} / \mathrm{s}$ in thermecmastor-z type thermal simulation test machine, and the $\mathrm{A}_{\mathrm{c} 3}$ of $3.5 \mathrm{Ni}$ steel was $787^{\circ} \mathrm{C}$. Based on $\mathrm{A}_{\mathrm{c} 3}$, normalizing and quenching temperature were set.

According to $3.5 \mathrm{Ni}$ steel delivery status, three heat treatment plans were designed: (1) normalizing and tempering; (2) quenching and tempering; (3) secondary quenching and tempering, including the first normal quenching process and the second intercritical quenching process.

\section{TEST RESULT AND ANALYSIS}

\section{A. Mechanical properties}

The mechanical properties were tested on WE- 60 hydraulic universal testing machine at ambient temperature, and on JB- 
30B impact testing machine between $-110{ }^{\circ} \mathrm{C}$ and $120{ }^{\circ} \mathrm{C}$, respectively.

TABLE 2 THE MECHANICAL PERFORMANCE ANALYSIS OF 3.5NI STEEL IN DIFFERENT HEAT TREATMENT PROCESS

\begin{tabular}{|c|c|c|c|c|c|c|c|c|}
\hline \multirow[t]{2}{*}{ Number } & \multirow{2}{*}{$\begin{array}{c}\text { Thickness } \\
(\mathrm{mm})\end{array}$} & \multirow{2}{*}{$\begin{array}{c}\text { heat } \\
\text { treatment } \\
\text { process }\end{array}$} & \multicolumn{2}{|c|}{$\begin{array}{l}\text { strength } \\
(\mathrm{MPa})\end{array}$} & \multirow{2}{*}{$\begin{array}{c}\begin{array}{c}\text { ductility } \\
(\%)\end{array} \\
\text { A }\end{array}$} & \multicolumn{3}{|c|}{$2 / \mathrm{KV}_{2}(\mathrm{~J})$} \\
\hline & & & $\mathrm{R}_{\mathrm{eL}}$ & $\mathrm{R}_{\mathrm{m}}$ & & $-101^{\circ} \mathrm{C}$ & $-110^{\circ} \mathrm{C}$ & $-120^{\circ} \mathrm{C}$ \\
\hline 1 & 36 & \multirow{2}{*}{$\mathrm{N}+\mathrm{T}$} & 410 & 520 & 32.5 & $193,165,191(183)$ & $124,110,156(130)$ & $21,37,52(37)$ \\
\hline 2 & 60 & & 415 & 520 & 34.5 & $194,186,145(175)$ & $51,33,62(49)$ & $15,23,26(21)$ \\
\hline 3 & 36 & \multirow{2}{*}{$\mathrm{Q} 1+\mathrm{T}$} & 480 & 565 & 29.5 & $252,290,264(269)$ & $240,250,210(233)$ & $132,174,142(149)$ \\
\hline 4 & 60 & & 470 & 560 & 34.5 & $239298246(261)$ & $198209162(190)$ & $106,129,58(98)$ \\
\hline 5 & 36 & \multirow{2}{*}{$\mathrm{Q} 1+\mathrm{Q} 2+\mathrm{T}$} & 490 & 575 & 32.5 & $263288255(269)$ & $251242190(228)$ & $205,218,224(216)$ \\
\hline 6 & 60 & & 485 & 570 & 31.5 & $273272265(270)$ & $221192177(197)$ & $198,187,120(168)$ \\
\hline
\end{tabular}

infuse: $\mathrm{N}$-normalizing, $\mathrm{Q} 1$ - once quenching, Q2 - secondary quenching, $\mathrm{T}$-tempering.

TABLE3 MicrostruCtURE OBSERVATION AND GRAIN SIZE ANALYSIS OF 3.5NI STEEL

\begin{tabular}{clcccc}
\hline No. & heat treatments & microstructure & inclusion & precipitate & average grain size \\
\hline 2 & N+T & B $+\mathrm{F}+\mathrm{P}(\mathrm{a}$ few $)$ & $\mathrm{B} 0.5 \mathrm{D} 0.5$ & $\begin{array}{c}\text { Ti, Nb spherical phase and a } \\
\text { small amount irregular particle phase }\end{array}$ & $47.07\left(\mu \mathrm{m}^{2}\right)$ \\
4 & $\mathrm{Q} 1+\mathrm{T}$ & $\mathrm{B}+\mathrm{F}$ & $\mathrm{B} 0.5$ & slight Ti、 Nb spherical phase & $32.66\left(\mu \mathrm{m}^{2}\right)$ \\
6 & $\mathrm{Q} 1+\mathrm{Q} 2+\mathrm{T}$ & $\mathrm{B}+\mathrm{F}$ & $\mathrm{B} 0.5$ & slight Ti、Nb spherical phase & $28.34\left(\mu^{2}\right)$ \\
\hline
\end{tabular}

infuse: B-bainite (include acicular, M/A island), F-ferrite, and P-pearlite.

It can be seen from the table 2, (1)The tensile properties of the $3.5 \mathrm{Ni}$ steel with different heat treatments can be satisfied technical requirements, but the strength of plates was higher after quenching and tempering or secondary quenching and tempering, while their elongation changed a little;(2) The -101 ${ }^{\circ} \mathrm{C}$ impact properties of the $3.5 \mathrm{Ni}$ steel with different heat treatments can also be satisfied, but the impact properties of the $3.5 \mathrm{Ni}$ steel after normalizing and tempering was lower than the others;(3) The low temperature toughness of plates was better after quenching and tempering or quenching and tempering twice, which can meet the impact properties at -110 ${ }^{\circ} \mathrm{C}$;(4) The low temperature toughness of plates after quenching and tempering twice was the best, and it can satisfy impact test requirements at $-120^{\circ} \mathrm{C}$.

\section{B. Microstructure observation and grain size analysis}

Microstructure of $3.5 \mathrm{Ni}$ steel was observed by OLYMPUS PME3-323UN optical microscope and Quanta 400 SEM, and equivalent grain size was analyzed by means of EBSD. Inclusion evaluation method was conducted according to GB/T 10561 《 Steel-Determination of content nonmetallic inclusions-Micrographic method using standards diagrams $》$. Its fine structures and precipitates were observed by JEM2000FX II TEM, and composition of precipitates were analyzed by INCA EDS.

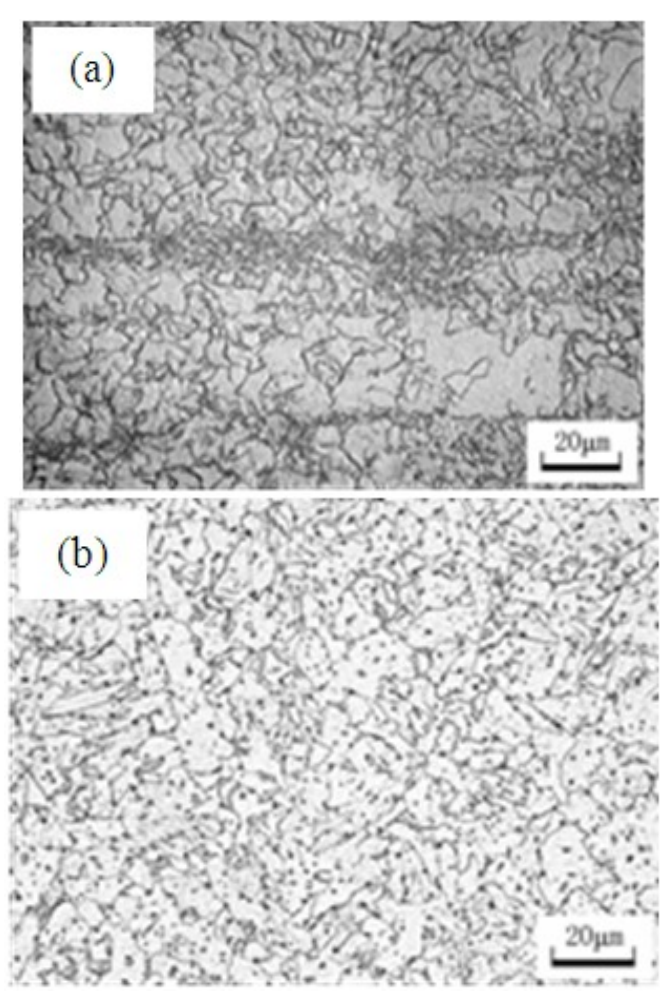




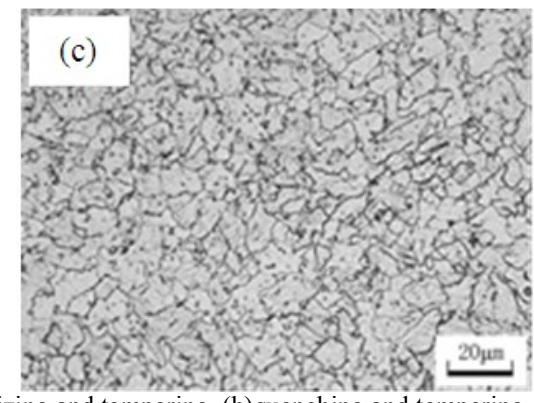

(a) Normalizing and tempering, (b)quenching and tempering, (c)secondary quenching and tempering

Figure 1 microstructure of testing steel
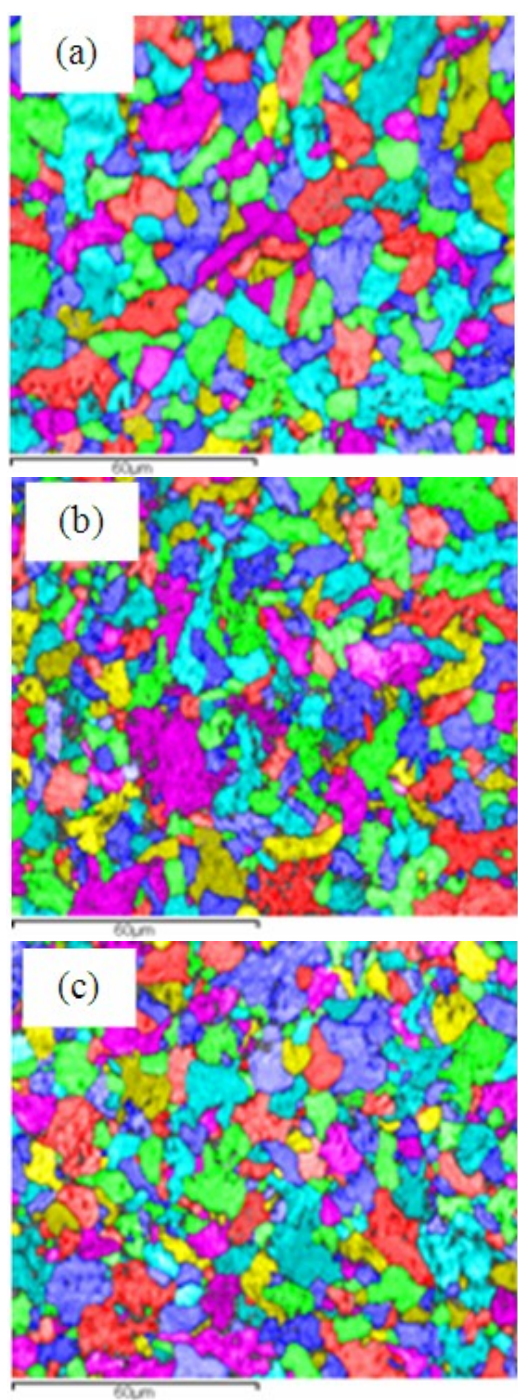

(a) Normalizing and tempering, (b)quenching and tempering, (c)secondary quenching and tempering

Figure 2 EBSD analysis results of secondary quenching and tempering

Table3、Figure 1 and Figure 2 shows that: the precipitates shape and microstructure of test steel (include normalizing, quenching and twice quenching) are different, microstructure in normalizing condition is bainite, ferrite and a small amount pearlite, while microstructure in quenching condition is bainite and ferrite. After quenching and tempering, average grain size of steel plate reduced significantly (from $47.07 \mu \mathrm{m}^{2}$ to $\left.32.66 \mu \mathrm{m}^{2}\right)$; average grain size of quenching and tempering twice further decreases (from $32.66 \mu \mathrm{m}^{2}$ to $28.34 \mu \mathrm{m}^{2}$ ).

\section{ANALYSIS AND DISCUSSION}

The related references show that, for thin plate of $3.5 \mathrm{Ni}$, grains and microstructure can be optimal by ordinary rolling and heat treatment of normalizing and tempering, properties for steel plate can be satisfied without complex process ${ }^{[3 \sim 5]}$. For thick plate, impact toughness is not stable, which was mainly caused by the less uniform microstructure and coarse grains. For microstructure at core of the thick plate, it can not be fully refined by ordinary rolling and normalizing.

After normalizing and tempering, bainite merges and part of its $\mathrm{M} / \mathrm{A}$ islands decompose into ferritic and cementite, and its grains size is uneven, which has effect on the impact toughness. After quenching and tempering, pearlite disappears and degenerate (carbide of the pearlite changed from lamellar into punctiform and globular), and the carbides in original microstructure become dispersion distribution, grains size are smaller than that at normalizing and tempering (from 47.07 $\mu \mathrm{m}^{2}$ to $32.66 \mu \mathrm{m}^{2}$ ). At the same time, there are many granular bainite distributing dispersedly, and strength of steel increases as grain size drops, as shown in figure 1 and figure 2 . The toughness of samples at $-110^{\circ} \mathrm{C}$ is good after quenching and tempering, but impact energy at $-120^{\circ} \mathrm{C}$ is not high. After quenching and tempering twice, carbides disappear, and retained austenite content increases, the grains size reduce further (average grain size decrease to $28.34 \mu \mathrm{m} 2$ ), impact toughness at $-120^{\circ} \mathrm{C}$ improved dramatically. Simultaneously, the steel still have more granular bainite, strength change a little.

\section{CONCLUSION}

(1) Uneven microstructure and coarse grains have bad effect on low temperature toughness of $3.5 \mathrm{Ni}$ steel.

(2) Good low temperature toughness for $3.5 \mathrm{Ni}$ steel can be required by normalizing and tempering for plate with thickness less than $36 \mathrm{~mm}$, and by quenched and tempered for plate with thickness between $36 \mathrm{~mm}$ and $60 \mathrm{~mm}$, and quenching and tempering toughness twice for plate with thickness above 60 $\mathrm{mm}$.

\section{REFERENCES}

[1] Chen Xiao, Qin Xiaozhong. High performance pressure vessel and pressure tube [M].Beijing : China Machine PRESS, 2007

[2] Zhang Yong. Current Situation and Development of Steel Used For Low Temperature Pressure Vessel [J]. Pressure Vessel 2006, 23(4):31.

[3] Li Jianhua. Effect of Heat Treatment on Low Temperature Toughness of 3.5Ni Steel [J].Physics Examination and Testing, Vo.26,No.6:9 10.

[4] Pang Huiyong. Study on Improving the Low Temperature Impact Toughness of 3.5Ni Heavy Plate [J]. Pressure Vessel Vol.26,No.10:5.

[5] Li Jianhua. Strengthening Mechanisms of Microalloyed 3.5Ni Steel [J].Materials Engineering 2010,No.5:9 10.

[6] Andrews K W. Empirical Formulae for Some Transformation Temperatures [J].Journal of the Iron and Steel Institute 1965, 203(7):721 